Jurnal Ilmu Dan Teknologi Kesehatan

Vol 7, No 2, Maret 2020,

ISSN: 2338-9095 (Print)

ISSN: 2338-9109 (online)

\title{
Quality Of Life Male Prisoners Based on Age and Education: Preliminary Studies
}

\author{
Prystia Riana Putri, Megah Andriany, Artika Nurrahima \\ Nursing Department, Faculty of Medicine, Diponegoro University of Semarang \\ Email:prystiarputri@gmail.com
}

\section{Article history}

Posted, Jan 30th, 2020

Reviewed, Feb 25th, 2020

Received, March 10th, 2020

\begin{abstract}
Prisoners in the correctional area are faced with unexpected situations and conditions. Prisoners ability to solve problems will affect the level of quality of life (QOL). However, research that focused on QOL levels based on age and education is not yet available, so this research is essential. This study applied a cross-sectional design with systemic random sampling and purposive sampling techniques. QoL measurements were carried out at 120 male prisoners using WHOQOL BREF instruments that have been tested as valid and reliable. The study was conducted in one of the Prisons in Central Java Province in September 2019. Inclusion criteria were no family visits, occupation of prisons for less than 18 months, general crime, and no cognitive impairment. The results showed that male prisoners with late adulthood and high school education had higher QOL mean rates of 88.5 and 87.6. The conclusion is the level of QOL related to age and high education.
\end{abstract}

Keywords: correctional; prisoners; quality of life.

\section{ABSTRAK}

Warga binaan pemasyarakatan (WBP) di Lembaga pemasyarakatan (Lapas) dihadapkan dengan situasi dan kondisi yang tidak diharapkan. Kemampuan WBP dalam menyelesaikan permasalahan akan mempengaruhi tingkat quality of life (QOL). Namun, penelitian yang berfokus pada tingkat QOL berdasarkan usia dan pendidikan belum tersedia, sehingga penelitian ini penting dilakukan. Penelitian ini menerapkan desain cross-sectional dengan teknik pengambilan sampel systemic random sampling dan purposive sampling. Pengukuran QOL dilakukan pada 120 WBP Laki-laki menggunakan instrumen WHOQOL BREF yang telah teruji valid dan reliabel. Penelitian dilakukan di salah satu Lapas Provinsi Jawa Tengah pada bulan September 2019. Kriteria inklusi sampel adalah tidak mendapat kunjungan keluarga, menghuni Lapas kurang dari 18 bulan, tindak pidana umum dan tidak mengalami gangguan kognitif. Hasil penelitian menunjukkan bahwa WBP Laki-laki dengan usia dewasa akhir dan pendidikan SMA memiliki tingkat rata-rata QOL lebih tinggi, yakni 88,5 dan 87,6. Simpulan yang didapat adalah tingkat QOL berhubungan dengan tingkatan usia dan tingginya pendidikan yang didapatkan. 
Kata kunci: lembaga pemasyarakatan; quality of life; warga binaan pemasyarakatan

\section{INTRODUCTION}

An increase in the number of prisoners occurs every year in correctional settings throughout Indonesia. The number of prisoners in one Central Java Province is estimated to increase in the last three years, namely 1472 prisoners in 2017, 1785 people in 2018, and 1949 people in December 2019 (Correctional Database System, 2019). Male prisoners who live in jail improve unpleasant conditions such as where roles change (Carlson and Cervera, 1991), away from family (Simha, 2019), successful freedom (Fredrickson, 2004; Hulley, Crewe, and Wright, 2015), and conditions prisons that are not in line with expectations (Liebling, 2008). The problems experienced by prisoners finally provide quality of life (QOL).

QOL is prisoners perception of their life, which is connected with the standard of living that has been set and governed by the culture and values in the environment (WHO, 1996). Preliminary studies conducted on five prisoners people revealed that they would feel dissatisfied feelings of being suspended in prison, sudden environmental changes that make it difficult, and encourage feelings of inability to develop themselves. Research reveals that prisoners have a different way in the process of maintaining QOL stability against every problem encountered (Lupien et al., 2009; Miller, Chen, and Parker, 2011). Thornton, Paterson, and Yeung (2013) revealed that the prisoners age level affects the process of problem-solving and ability in adaptive coping management. Research conducted by Luy et al. (2019) showed that the level of education also influenced prisoners in viewing the problems faced in jail.

QOL-related research on prisoners is not yet available, so this research needs to be done as a description of the QOL level based on age and education owned by prisoners. Data regarding QOL measurement owned by prisoners can facilitate nurses in formulating appropriate nursing actions to improve the expected outcome of health improvement.

\section{METHOD}

This research is a quantitative study with a cross-sectional design. The study population was chosen randomly through systemic random sampling with a purposive sampling method in one of the 
Lapas Men in Central Java Province and conducted in September 2019. The inclusion criteria of sample selection are prisoners who do not get family visits directly (residing outside the city), inhabiting prisons for less than 18 months, general crime, and not experiencing cognitive impairment. Randomization was carried out to determine the WBP representative block bearing in mind that there were 12 blocks in prison so that a total sample of 120 male prisoners was obtained. Prisoners QOL was measured using the WHOQOL-BREF instrument, which has been proven valid and reliable with $r=0.0466-0.786$ and $R=0.859$ (Pheny, Raymondalexas, and Rahmat, 2014). The WHOQOL-BREF instrument consists of 26 questions. QoL measurement results are interpreted through the mean values per age and education category.

An ethical feasibility test has been conducted at the Ethics Committee of the Nursing Department of the Faculty of Medicine, the University of Diponegoro under

number

61/EC/KEPK/D.Kep/IX/2019 and declared to have passed the test. The results obtained were analyzed using the univariate analysis to find descriptive statistics of age and education on the QOL level of male prisoners. Data is presented in a frequency distribution table in the form of a percentage of results.

\section{RESULTS AND DISCUSSION}

The results obtained from the prisoners QOL measurement based on age and education are as follows.

Table 1. Measurement results based on age and education $(n=120)$

\begin{tabular}{clcc}
\hline No & \multicolumn{1}{c}{ Characteristic } & Mean QOL & n \\
\hline 1 & Age & & \\
\hline & Late teens (17-25 years old) & 84,3 & 39 \\
\hline Early adult (26-35 years old) & 85,0 & 50 \\
\hline Late adult (36-45 years old) & 88,5 & 31 \\
\hline & & \\
\hline 2 & Education & & 47 \\
\hline$\quad$ Elementary school (ES) & 84,8 & 47 \\
\hline & Junior high school (JHS) & 86,9 & 26 \\
\hline & Senior high school (SHS) & 87,6 & \\
\hline
\end{tabular}

The results based on table 1 show that in the age characteristics, the late adult category had a higher average QOL of 88.5. In comparison, the late adolescent category had a lower average QOL of 84.3. This is in line with studies that reveal that the category of late adulthood has an increase in physical activity and is more 
expressive towards something that is a target of life so that it gives an impact on increasing satisfaction in life (Lum, 2013; Matz-Costa et al., 2014). Medley (1980), in his research, revealed that age affects one's emotional maturity so that satisfaction in life is easier to achieve.

The results based on the education category in table 1 show that male prisoners with the last high school education have a greater QOL value of 87.6 compared to male prisoners who have an elementary school education. HalpernManners et al. (2016) revealed that the education undertaken by prisoners is directly proportional to the level of mental readiness owned. Higher education levels encourage prisoners to have a positive mindset and good coping mechanisms. Education instills knowledge in WBP to see past mistakes as lessons and encourages self-improvement (Laaksonen et al., 2008; Denney et al., 2010). WBP, which can maintain positive thinking even though it is in a condition that is not by expectations, will have a good QOL (Armenta, Fritz, and Lyubomirsky, 2016).

Prisoners with adult age and higher education levels are proven to have their strategies in solving problems so that the risk of anxiety and depression can be avoided (Smrtinik Vitulic and Prosen, 2016). Prisoners ability to adapt and manage negative emotions will affect QOL (Ventegodt, Andersen, and Merrick, 2014).

\section{CONCLUSION}

The results showed that the characteristics of age and education affected the QOL level possessed by WBP. Nurses, as providers of nursing care, can manage nursing actions by first making adjustments based on the category of WBP so that the results produced can be as expected.

\section{REFERENCE}

Armenta, C. N., Fritz, M. M., and Lyubomirsky, S. 2016. 'Functions of positive emotions: Gratitude as a motivator of self-improvement and positive change', pp. 1-8. DOI: $10.1177 / 1754073916669596$.

Carlson, B. E., and Cervera, N. 1991. 'Inmates and their families: Conjugal visits, family contact, and family functioning, Criminal Justice and Behavior, 18, pp. 318-331. DOI: 10.1177/0093854891018003005.

Denney, J. T. et al. 2010. 'Education inequilty in mortality: The age and gender-specific mediating effects of cigarette smoking', Social Science Res, 39(4), pp. 662-673. DOI: 10.1016/j.ssresearch.2010.02.007.

Departemen Kesehatan Republik Indonesia. 2009. Kategori umur 
manusia.

Fredrickson, B. L. 2004. 'The broaden and build theory of positive emotions', The Royal Society, (August), pp. 1367-1377.

DOI: 10.1098/rstb.2004.1512.

Halpern-Manners, A. et al. 2016. 'The relationship between education and mental health: New evidence from a discordant twin study', Social Forces, 95(1), pp. 107-131. DOI: 10.1093/sf/sow035.

Hulley, S., Crewe, B., and Wright, S. 2015. 'Re-examining the problems of long-term imprisonment', British Journal of Criminology, (April 2014). DOI: 10.1093/bjc/azv077.

Laaksonen, M. et al. 2008. 'Health behaviors as explanations for educational level differences in cardiovascular and all-cause mortality: A follow-up of 60000 men and women over 23 years', European Journal of Public Health, 18(1), pp. 38-43. DOI: 10.1093/eurpub/ckm051.

Liebling, A. 2008. 'Incentives and earned privileges revisited: Fairness, discretion, and the quality of prison life', Journal of Scandinavian Studies in Criminology and Crime Prevention, pp. 25-42. DOI: $10.1080 / 14043850802450773$.

Lum, T. Y. sang. 2013. 'Advancing research on productive aging activities in greater Chinese societies', Ageing International, 38(2), pp. 171-178. DOI: 10.1007/s12126-012-9171-2.

Lupien, S. J. et al. 2009. 'Effects of stress throughout the lifespan on the brain, behavior and cognition', Nature Reviews Neuroscience, 10(6), pp.
434-445. DOI: 10.1038/nrn2639.

Luy, M. et al. 2019. 'The impact of increasing education levels on rising life expectancy: A decomposition analysis for Italy, Denmark, and the USA', Genus. Genus, 75(1). DOI: 10.1186/s41118-019-0055-0.

Matz-Costa, C. et al. 2014. 'Differential impact of multiple levels of productive activity engagement on psychological well-being in middle and later life', Gerontologist, 54(2), pp. 277-289. DOI: 10.1093/geront/gns148.

Medley, M. L. 1980. 'Life satisfaction across four stages of adult life', International Journal of Aging and Human Development, 11(3), pp. 193-209. DOI: 10.2190/D4LGALJQ-8850-GYDV.

Miller, G. E., Chen, E., and Parker, K. J. 2011. 'Psychological stress in childhood and susceptibility to the chronic diseases of aging: Moving toward a model of behavioral and biological mechanisms', Psychological Bulletin, 137(6), pp. 959-997. DOI: 10.1037/a0024768.

Pheny, S., Raymondalexas, C. and Rahmat, I. 2014. Association between adversity quotient and quality of life among drug abusers in Narcotics Penitentiary Class IIa Yogyakarta. Universitas Gadjah Mada.

Riyanto, A. 2011. Aplikasi metodologi penelitian kesehatan. Yogyakarta: Nuha Medika.

Simha, S. 2019. 'The impact of family separation on immigrant and refugee families', North Carolina medical journal, 80(2), pp. 95-96. DOI: 10.18043/ncm.80.2.95. 
Sistem Database Pemasyarakatan. 2019. 'Data penghuni Lapas kelas I Semarang'.

Smrtinik Vitulic, H., and Prosen, S. 2016. 'Coping and emotion regulation strategies in adulthood: Specificities regarding age, gender, and level of education', 25(1), pp. 43-62. DOI: 10.5559/di.25.1.03.

Thornton, W. L., Paterson, T. S. E., and Yeung, S. E. 2013. 'Age differences in everyday problem solving: The role of problem context', International Journal of Behavioral Development, 37(1), pp. 13-20. DOI: $10.1177 / 0165025412454028$.

Ventegodt, S., Andersen, N. J., and Merrick, J. 2014. 'Quality of Life Philosophy I. Quality of Life, Happiness, and Meaning in Life', (January 2004). DOI: 10.1100/tsw.2003.102.

WHO. 1996. 'WHOQOL-BREF introduction, administration, scoring, and generic version of the assessment', (December). 